\title{
RECENT TRENDS IN URBAN COOPERATIVE DEVELOPMENT
}

\author{
JERRY VOORHIs*
}

The history of consumer cooperatives in the cities of America is one of ups and downs, successes and failures. In rural America both marketing and purchasing cooperatives have enjoyed a fairly steady growth and expansion through the years. From a third to a half of American farmers are today cooperative members, and many of them belong to two or three such organizations serving different rural needs. Marketing cooperatives, co-ops producing, purchasing, and distributing supplies required for farm operation or household needs, electric (REA) cooperativesall these have been, on the whole, highly successful among farmers, so that they are able to exert a significant influence on the economic welfare of rural America as well as on the lives of farm families.

For a variety of reasons, the story in the cities has been a different one. Probably the fundamental reason for the difference has been that farmers as a group have faced economic circumstances which made the need for cooperation very evident. Workers in the cities have, it is true, organized labor unions, which in a number of respects are similar to farmers' marketing cooperatives, since both attempt to protect the incomes of large producer groups who, as individual "bargainers," would find themselves in an almost helpless economic position. But up to the present time the people of American cities have apparently felt little need of using the methods of cooperation to protect their living standards, the purchasing power of their money, their health, their opportunity for home ownership, or their general security.

Exception must be made to this statement in one respect at least. The credit unions, which of course are basic financial cooperatives, have gained a membership in the United States of some four million and are able, therefore, to exert a very salutary influence upon the financial security of the people. Not only are credit union members enabled to control and obtain the benefit of their own savings (indeed, to pay interest to themselves!), but the competitive impact of the creditunion movement has shifted a considerable part of the small-loan business of the country from loan sharks, charging usurious rates of interest, to the banks, which have rather suddenly come to the realization that they can make small loans at fairly reasonable rates of interest if they really want to. In recent years, the growth of the Ohio Farm Bureau Mutual and other cooperative insurance companies and

- Executive Secretary of the Cooperative League of the U.S.A. Member of the House of Representatives from California, r937-rg47. 
the extension of the cooperative advantages of this insurance to farm and city people alike has had marked effect in bringing down insurance premium rates and introducing an element of democratic control over a significant segment of the people's savings.

What most people think of, however, when they hear the words 'consumers' cooperative," is a store. Generally they think of a grocery store. It is true that in England, Scandinavia, and other countries where cooperatives have grown largest and accomplished most, the heart of cooperative business has been the grocery store. It is around such a store that the basic consumer interest necessarily centers; and it is there, accordingly, that the best chance for the development of a genuine cooperative spirit among members exists. Unfortunately, for American cooperation, it is also in the grocery business that the greatest integration has taken place in the trade of the United States. Retail margins have, in the case of many items, been reduced almost to the vanishing point. Thus, except where certain circumstances have combined to enhance the chances for success, grocery store urban cooperatives have had a hard time in this country.

What are those circumstances?

In the first place, the large city cooperative market has had a much more difficult situation to face than has the cooperative general store in the small town, where competition is less keen, margins are generally a good deal higher, and a wider variety of goods, including some where substantial mark-ups prevail, is handled. In the second place, one element essential to the success of cooperatives is a high degree of mutual loyalty and esprit de corps among the membership. This is harder to develop in the center of a big city than in a small community. It can be developed most easily among a group of people with common racial, linguistic, or national ties; but even in such a group it requires a vigorous and effective educational program in cooperative principles. In the third place, the management of a cooperative store must be in competent hands. A higher degree of skill and a greater variety of talents are required than for the management of competing establishments. The co-op manager must be not only a skilled merchandiser, but also a wise buyer and, because of the democratic organization of cooperative business, a master in the art of personal relationships. Where these circumstances have combined, or where even the last two have been present in a marked degree, urban consumer cooperatives have been successful in the United States. An increasing number of them are succeeding right now, partly because some lessons have been learned the hard way.

The principal factor in the situation, however, is a vicious circle which must in some manner be broken if urban cooperatives are to enjoy a growth corresponding to that of their counterparts on the land. This circle operates as follows: American city-dwellers are an impatient people. Many of them live closer to the margin of immediate need than do farm families. They say, in effect, "Show us some immediate prospects of concrete economic gains and we will join your cooperative." 
But, especially in the low-margin fields such as groceries, the most essential condition of substantial savings by cooperatives for their members is a much larger volume of total cooperative business. Only large volume can make wholesale operations efficient, and only large volume can make safe the entry on a broader scale into processing and production. In order to assure potential members of immediate savings there must be larger volume, but to get the larger volume there must be a great increase in the number of loyal cooperative member-patrons. It is not always remembered that in the case of most, it not all, successful cooperatives among American farmers it was necessary for the members to stand loyally by their venture through a period when they could have gained immediate benefit for themselves by patronizing the people who were trying to run the cooperative out of business.

The action of a number of labor unions in turning themselves into grocery stores for the purchase of supplies for, and sale to, their members at wholesale prices is illustrative of the desire-and the need-of industrial workers for immediate relief from high prices. It is very important to point out, as the cooperatives and responsible labor leaders have continuously done, that these operations have not been cooperatives in any sense. They have simply been purchase and sale operations planned as a dramatic protest against high living costs.

Out of these experiences, out of an increasing concern on the part of many millions of Americans about their economic future, and also out of the realization that increased income means nothing if prices go up even faster, has come a wave of genuine interest in cooperatives in city after city throughout the nation. Especially is this true among certain groups, by far the largest of which is organized labor. What this interest will produce in the way of sound, permanent cooperative organization will depend in large part upon what can be done to break the vicious circle described above.

Attempts to do exactly that are now being tested in practical experience. One such venture is the construction of three large department stores by the Cooperative Development Corporation with funds bequeathed for the promotion of cooperation by the late Edward A. Filene. The Board in control of these funds hopes that shares in these department stores can be sold to their customers in sufficient amounts to replace all the C.D.C.'s money, whereupon the stores would become true consumer cooperatives. If the first stores are successful, more will be built. These stores will have the advantages of handling a wide variety of items, many of which are those on which consumers usually pay high mark-ups. Furthermore, they will be large-volume operations.

Of even greater significance may be a new type of approach to the organization of cooperatives now being undertaken in some industrial areas, notably the vicinity of Detroit. Briefly, it consists of starting the business of a new cooperative, or sharply expanding the operations of an existing one, by conducting "food fairs," where selected staple grocery, household-supply, and home-appliance items are bought: in one large shipment from a wholesale cooperative and sold on an ap- 
pointed day or days either "off the truck," from a union hall, or at some other temporary location. Sales are not at "cost" nor at "wholesale prices," but at a mark-up large enough to allow for safety and to make some patronage refund likely in the near future. Every effort is made to sell not only groceries but also shares of stock in the cooperative. So long as the only items sold are those upon which margins are sufficient to insure a saving for the purchaser without danger to the cooperative, it is possible in this manner to bring some immediate benefits. At the same time new cooperators are being enlisted in sufficient numbers, it is hoped, to make possible the large volume which is so essential.

After the food fairs and other devices have brought in enough capital to make it safe, the next step in this new cooperative method is to lease a building-but not a fancy store building. Instead, a very simple structure is secured, located where rail or truck delivery will be easiest. There the co-op starts a new type of distribution to consumers. Items again are limited to those on which margins in the chains and other stores are such that it is almost certain that savings can be made for the consumer-patrons if they buy at the co-op. The entire operation is streamlined as much as possible, case-lot and bulk sales are encouraged, and self-service is the rule. ${ }^{1}$

The results of these new departures cannot yet be judged. Perhaps they will not be as successful as some signs indicate they may be. Their success will depend, more than on any other factor, upon whether considerable numbers of American consumers are willing to change their buying habits sufficiently to put all their dollars into solid value in goods instead of spending part of those dollars for convenience, attractive shopping surroundings, and the costs of expensive advertising. Even if such an attitude should not develop on a large scale, there is a good chance that cooperative membership will have been substantially increased and perhaps enough volume added to break the circle. Furthermore, there is nothing to prevent a co-op, after trying this low-cost distribution method, from branching out into more traditional types of store operations, since comparatively little will have been invested in plant or facilities.

There are also signs on the horizon that the interest of American city-dwellers in cooperatives is deeper and more determined than ever before, even if we disregard the new departures just discussed. For example, Michigan labor unions, largely the United Automobile Workers, recently purchased $\$ 150,000$ of preferred stock in Central States Cooperative to enable that wholesale cooperative to open a warehouse in Detroit. There is a growing impatience with inefficient methods and an increasing realization of the necessity of high-calibre management and of closer coordination between retail and wholesale cooperatives. There is active work being done to determine how-in what specific services and commoditiescooperatives can render the greatest service to city consumers, and a readiness to change old patterns, if necessary, to accomplish this. A new organization has been

${ }^{1}$ Standard wages are of course paid to employed personnel. 
formed, or rather an old one revived, wherein the contributions of foundations, labor unions, cooperatives and other interested groups can be pooled for the purpose of encouraging and guiding the development of urban cooperatives. This is known as the Council for Cooperative Development. The Cooperative League is making available all the resources and personnel which it can spare from other essential work for this effort.

The situation is one of movement and ferment. Out of it may come a substantial development of urban cooperatives in the United States. In my judgment, the chance for such a development depends upon the morale of the interested people more than upon any other single factor. It depends, as the success of cooperative endeavors and enterprises all through history has depended, upon the number of people who see a goal of "a fifth of America's business in the control of the people," and who see it so clearly that they will loyally support their cooperatives in this period of development even if the immediate financial returns are not great. 